\title{
ARTICLE
}

\section{0,000 Counts of Aiding and Abetting Murder}

\author{
Fabian Bernhart ${ }^{\star}$, Alexander Tanner ${ }^{\star *}$, Falaq Ahmad ${ }^{\star * \star}$, Joyce Galvano ${ }^{\star \star * \star}$ and Tanja Herde ${ }^{\star \star * * *}$
}

(Accepted 04 December 2019)

\begin{abstract}
More than seventy years after the end of the Second World War, atrocities committed under the National Socialist regime still continue to occupy the courts in Germany. The recent case of Oscar Gröning raised a number of highly relevant legal issues, particularly with regard to the degree of participation in criminal offenses in general, and more specifically, with regard to the possible level of criminal liability of individuals who, as part of a large-scale "killing machinery", were acting under the command of superiors and, as such, not directly involved in the acts of homicide which were perpetrated. Different theories pertaining to the level of participation are analyzed, and the German Federal Court's decision in the Gröning case is dealt with in detail.
\end{abstract}

Keywords: National Socialist criminals; German criminal law; Holocaust; aiding and abetting murder; Gröning

\section{A. Introduction}

Did the German courts fail to administer justice with regard to the heinous offenses committed during the period of National Socialism in Germany? In a nation influenced by such a cruel past and once permeated by former Nazis, the reassessment of past mistakes has always been of the utmost importance. Nevertheless, stimulated by the Amnesty Acts of 1949 and 1954 (Straffreiheitsgesetze), a stagnation in prosecutions occurred briefly after the founding of the Federal Republic of Germany (FRG). ${ }^{1}$ As the Act was only applicable to offenses punished with a custodial sentence not exceeding twelve months, ${ }^{2}$ notable proceedings such as the Auschwitz

\footnotetext{
${ }^{\star}$ The author is a student at Friedrich-Alexander University Erlangen-Nürnberg School of Law affiliated to Capital Market Law, Corporate Law and Comparative Law.

${ }^{* *}$ The author is a student at Friedrich-Alexander University Erlangen-Nürnberg School of Law interested in Criminal and International Law.

${ }^{* * *}$ The author is a student at Friedrich-Alexander University Erlangen-Nürnberg School of Law with focus on European and International Law.

${ }^{* * * *}$ The author acquired a graduate degree in German Law in January 2020 and currently conducts a legal clerkship at the Higher Regional Court in Nuremberg.

${ }^{* * * *}$ The author is a student at Friedrich-Alexander-University Erlangen-Nürnberg School of Law with focus on Criminal and International Criminal Law.

The authors are grateful to Dr. Kevin Pike and Prof. Dr. Christoph Safferling participating in this project for language review and comments on an earlier version, but first and foremost for granting the opportunity to publish as part of the technical language training course for legal English at the Friedrich-Alexander University Erlangen-Nürnberg School of Law.

${ }^{1}$ Andreas Eichmüller, Keine Generalamnestie: Die Strafverfolgung von NS-Verbrechen IN DER FrÜheN BundESREPUBLIK 41 (2012).

${ }^{2}$ Manfred Görtemaker \& Christoph Safferling, Die Rosenburg: Das Bundesministerium der Justiz und die NS-Vergangenheit - EINE Bestandsaufnahme 182 (2d ed. 2013).
}

(c) The Author(s), 2020. Published by Cambridge University Press on behalf of the German Law Journal. This is an Open Access article, distributed under the terms of the Creative Commons Attribution licence (http://creativecommons.org/licenses/by/4.0/), which permits unrestricted re-use, distribution, and reproduction in any medium, provided the original work is properly cited. 
Prozess, instigated by the public prosecutor Fritz Bauer, still attracted the attention of the public. ${ }^{3}$ Such cases, however, lost a great deal of their relevance due to the Introductory Act to the Regulatory Offences Act (Einführungsgesetz zum Ordnungswidrigkeitengesetz; EGOWiG) which came into force on October 1, 1968. ${ }^{4}$ In accordance with this law, mitigation was required if special personal characteristics establishing the principal's liability were absent in the participant-corresponding to the current statutory situation pursuant to $\$ \$ 28 \mathrm{I}, 49$ I of the German Criminal Code (Strafgesetzbuch; StGB). ${ }^{5}$ According to the Fifth Criminal Senate of the German Federal Court of Justice (Bundesgerichtshof; $B G H$ ), the reduction of the statutory range of punishment consequently entailed a reduction in the statutory limitation to fifteen years as of May 8, 1945. ${ }^{6}$ As such, all offenses considered to be aiding and abetting murder became barred by statute if proceedings had not been initiated before May 8, 1960, ${ }^{7}$ and the so-called cold amnesty was brought into being. ${ }^{8}$ After innumerable debates on the subject of the statute of limitations, especially for the aforementioned crimes in light of the National Socialist genocide, the West German Parliament decided to abolish the statute of limitations for genocide and murder ( $\$ 211 \mathrm{StGB}$ ) in order to enable the BGH to adjudicate upon National Socialism cases, such as the case concerning Oskar Gröning. ${ }^{9}$

On September 20, 2016, this new National Socialism case incriminating Oskar Gröning was brought before theThird Senate of the BGH. Oskar Gröning was the one and only defendant who showed remorse and regret during a National Socialism trial. He confronted himself with the Private Accessory Prosecutors and even dedicated his closing speech to them with the words, "Auschwitz was a place we shouldn't have been a part of. I should have left it. I explicitly apologise for not having acted like this." 10 This case can be constituted as a historical and highly significant step $^{11}$ that permitted the $\mathrm{BGH}$ to validate the court ruling in the landmark case of John Demjanjuk ${ }^{12}$ - a conviction which never took legal effect due to Demjanjuk's death in March 2012. ${ }^{13}$ The decision of the BGH with regards to Gröning, as such, enables the German justice system to uphold and to sustain the ideals and theories of the Demjanjuk case and, above all,

\footnotetext{
${ }^{3}$ Jan Thiessen, Fritz Bauer - zur schwierigen Rezeption eines Lebenswerks, 70 JURISTENZEITUNG 1069, 1077 (2015).

${ }^{4}$ Einführungsgesetz zum Gesetz über Ordnungswidrigkeiten [EGOWiG] [Introductory Act to the Regulatory Offenses Act], May 24, 1968, BGBL I at 503 [hereinafter Introductory Regulatory Offenses Act].

${ }^{5}$ Christoph Safferling, Anmerkung, 72 JURISTEnZeitung 258, 258 (2017) (commenting on Bundesgerichtshof [BGH] [Federal Court of Justice] Case No. 3 StR 49/16, 498, (Sept. 20, 2016), http://juris.bundesgerichtshof.de/cgi-bin/rechtsprechung/document. py?Gericht=bgh\&Art=en\&sid=bbe46accfd2b17f4b9468d823568d02c\&nr=76630\&linked=pm\&Blank=1); STRAFGESETZBUCH [StGB] [PENAL CODE].

${ }^{6}$ Bundesgerichtshof [BGH] [Federal Court of Justice] May 20, 1969, Neue Juristische WochensCHrift [NJW] 1181, 1183, 1963 (Ger.).

${ }^{7}$ GÖRTEMAKER \& SAFFERLING, supra note 2, at 56.

${ }^{8}$ Manfred Görtemaker \& Christoph SafFerling, Die Akte Rosenburg: Das Bundesministerium der Justiz Und die NS-ZeIT 399 (2016).

${ }^{9}$ Sechzehntes Strafrechtsänderungsgesetz [16. StrÄndG] [Sixteenth Criminal Law Amendment Act], July 16, 1979, BGBL I at 1046 .

${ }^{10}$ Thomas Walther, Nebenkläger im Prozess: Gerechtigkeit ist den Opfern geschuldet, in DIE LETZTEN NS-VERFAHREN 153, 175 (Frank Lüttig \& Jens Lehmann eds., 2017).

${ }^{11}$ Claus Roxin, Beihilfe zum Mord durch Dienst im Konzentrationslager Auschwitz, 2017 JURISTISCHE RUNDSCHAU 83, 91 (2017) (commenting on Bundesgerichtshof [BGH] [Federal Court of Justice] Case No. 3 StR 49/16, 498, (Sept. 20, 2016), http://juris.bundesgerichtshof.de/cgi-bin/rechtsprechung/document.py?Gericht=bgh\&Art=en\&sid=bbe46accfd2b17f4 b9468d823568d02c\&nr=76630\&linked $=$ pm\&Blank=1).

${ }^{12}$ Landgericht München II [LG Munich II] [Munich District Court] Case No. 1 Ks 115 Js 12496/08, (May 12, 2011), https:// dejure.org/dienste/vernetzung/rechtsprechung?Text=1\%20Ks\%20115\%20Js\%2012496/08. The Landgericht convicted John Demjanjuk of aiding and abetting murder on 28,060 counts even though not a single offense could be directly attributed to him individually (funktionale Beihilfe). His service in Sobibor made him part of the National Socialist killing machine. This was essentially a rectification of earlier judgments where a direct contribution to the killing had always been required.

${ }^{13}$ Lawrence Douglas, The Right Wrong Man: John Demjanjuk and the Last Great Nazi War Crimes Trial 257 (2016).
} 
it sets a precedent. Subsequently, on March 9, 2018, Gröning died at the age of 96 without serving his custodial sentence.

\section{B. Description of Facts}

The Third Senate of the BGH confirmed the decision of the Regional Court of Lüneburg (Landgericht Lüneburg), which had found the former SS member, Oskar Gröning, guilty of aiding and abetting murder in 300,000 cases and sentenced him to a four-year term of imprisonment. The accused, as an "ardent National Socialist," had voluntarily joined the SS and had worked as an accountant and as one of the concentration-camp guards where he supported a regime responsible for mass murder.

In September 1942, Gröning's superiors transferred him to Auschwitz to take part in Operation Reinhard, which was part of "the final solution to the Jewish question"-a systematic extermination of European Jews. At the turn of 1942-43, the extermination camp in Auschwitz-Birkenau had been entirely converted into a concentration camp, including four enormous gas chambers with a daily death toll of up to 5,000 people. In March 1944, the SS began with the extermination of Hungarian Jews, the so-called Hungarian Action, which was based on the model of Operation Reinhard. For this purpose, the Eichmann commando moved to Hungary. Otto Adolf Eichmann, a former German Nazi SS Lieutenant Colonel, was one of the major organizers of the Holocaust. Eichmann was instructed by SS Lieutenant General Reinhard Heydrich, the main culprit behind Operation Reinhard.

After Hungary was occupied by the Germans, the SS transported Jews to Auschwitz between May and July 1944, in order to be systematically exterminated, just as the Jews during Operation Reinhard had been. The SS prepared for the Hungarian Action by laying a new track, which terminated within the Auschwitz concentration camp, where it was further divided into three tracks. On this account, the SS unloaded the transported convicts only a few meters in front of the gas chambers. There, the SS ordered the convicts to leave their luggage on the platform. The SS told the convicts their luggage would be brought to them subsequently. The guilelessness of the victims was thereby maintained. Afterwards, the SS brought the convicts to the on-site SS doctor after undergoing gender segregation to determine who was capable of work and who was incapacitated for work and should therefore be killed immediately.

The SS exterminated those who were capable of working through labor. The SS directly guided around $80-90 \%$ of the prisoners into gas chambers where the SS members pretended to have showers. Subsequently, the Jews were requested to remove their clothes and to remember the place where they left them. Eventually, in gas chambers they died an agonizing death through the pesticide Zyklon B, which was hydrogen cyanide. Over the course of the Hungarian Action, 141 trains arrived in Auschwitz with 430,000 people. As the victims who were immediately killed were not registered, the Regional Court of Lüneburg was unable to determine the precise number of victims. Erring on the side of caution in favor of the accused, the Court determined 300,000 cases.

Oskar Gröning was active in Operation Reinhard and in the Hungarian Action, where he stood guard as trainloads of human beings entered the camp. Likewise, he counted money taken from the luggage of the murdered Jews and sent it back to SS headquarters in Berlin. In particular, Oskar Gröning had already had knowledge of every sequence of events since Operation Reinhard. Besides, he was well aware that he was supporting killing machines and approved of this, wherefore the Regional Court of Lüneburg found him guilty of aiding and abetting murder in 300,000 cases. The accused sought leave to appeal against this decision. ${ }^{14}$

\footnotetext{
${ }^{14}$ Bundesgerichtshof [BGH] [Federal Court of Justice], Case No. 3 StR 49/16, (Sept. 20, 2016), http://juris.bundesgerichtshof. de/cgi-bin/rechtsprechung/document.py?Gericht=bgh\&Art=en\&sid=bbe46accfd2b17f4b9468d823568d02c\&nr=76630\& linked $=\mathrm{pm} \&$ Blank $=1$.
} 


\section{Judgment by the BGH}

The BGH upheld the judgment of the Regional Court of Lüneburg and consequently dismissed the appeal filed by the accused. At least 300,000 people had been cruelly murdered by stealth in the Auschwitz concentration camp during the Hungarian Action. The BGH asserted the assumption of the Regional Court of Lüneburg according to which Gröning had aided and abetted all 300,000 of those murders.

Pursuant to the general principle of $\$ 27$ StGB, every action that objectively facilitates or enhances the causation of an offense's successful commission is considered to be aiding and abetting, provided that the act committed is a result crime (Erfolgsdelikt), although it is not necessary for the action to be causal for the specific result. ${ }^{15}$ Should the offense be committed as part of a joint criminal enterprise, for example, a gang or a criminal or terrorist association, not every act committed is generally imputable to the sole member merely due to his affiliation. Moreover, it is necessary to examine the precise contribution of each participant in every case. ${ }^{16}$ This regulation is similarly applicable in the context of state-organized mass crimes, although certain particularities have to be adhered to. On the one hand, there were people who were only responsible in political, administrative, or military hierarchical positions without personally killing anybody during the time of the Nazi regime. On the other hand, there were people who were only following the directions they were given by superiors but were in direct contact with the specific acts of murder.

Assessed as such, the BGH confirmed that the Regional Court of Lüneburg had not made an error of assessment in concluding that Gröning aided and abetted the murders committed during the Hungarian Action, where the victims were killed in the gas chambers immediately after arrival and selection. The stipulation under $\$ 27$ StGB is certainly applicable to the death of victims where Gröning had been on duty at the ramp as they arrived at the concentration camp. He aided the SS members who were selecting and instantaneously killing the victims by dispersing Zyklon B inside the gas chambers. Meanwhile, Gröning guarded the victims' assets in order to maintain their guilelessness, on the one hand, and on the other hand, to be part of the overall posture of threat and intimidation which would stifle any thoughts of resisting or attempting to break free.

The crimes committed against the victims at a time when the accused was not on duty are nevertheless still attributable to Gröning. It cannot be ascertained whether the accused actually physically or psychologically influenced the medicals or the SS members during the selection or the murders by simply fulfilling his general tasks. Gröning, however, aided the superior authority of the Nazi regime and the SS which commanded the Hungarian Action in spring 1944 by performing his general duties in Auschwitz. It was essential for the Nazi regime, and thus the Hungarian Action, to possess a perfectly organized and structured industrial homicide machinery with willing and obedient subordinates. The Auschwitz concentration camp, and especially the extermination camp in Auschwitz-Birkenau, were a part thereof. Their intent and their commands for the performance of the planned deportation and killing of hundreds of thousands of Hungarian Jews were hereby significantly formed and supported. Gröning was already a part of the killing machinery of the Auschwitz concentration camp at the moment of the command of the Hungarian Action by serving at the ramp upon the victims' arrival, as it was on the roster. Moreover, the accused was involved in the utilization of the victims' assets after they were killed, whereby he knew that the SS profited from the victims' assets. It was not important to the Nazi regime who oversaw the duties; the only important fact was the performance as commanded in order to ensure the unobstructed progress of the Hungarian Action. Gröning was well aware of the

\footnotetext{
${ }^{15}$ Bundesgerichtshof [BGH] [Federal Court of Justice] Mar. 8, 2001, NeuE JuRISTISChe WochENSChrift [NJW] 2409, 2410, 2001.

${ }^{16}$ Bundesgerichtshof [BGH] [Federal Court of Justice] Dec. 23, 2009, Neue JuRISTISChe WochENSChrift [NJW] 445, 447, 2009.
} 
process and intentionally accepted it. He was fully informed of the crimes committed only a short time after his arrival in Auschwitz, complied with the organization of the camp to prevent himself from being sent to the frontline, and followed the commands given. Furthermore, the accused knew that the authorities could instantly plan and perform exterminations in Auschwitz if he, in collusion with others, continued to form the basis for the industrial killing machinery.

The decision of the Third Senate of the BGH is also not at odds with judgments passed by other senates of the BGH. It is not a matter of passing judgment on Gröning because he did something during the time of the extermination of Hungarian Jews in Auschwitz. Besides, it is not every single crime committed in Auschwitz that is attributed to him. It is a matter of fact that Gröning acted in a particular manner with direct reference to the organized killing machinery of Auschwitz before and during the Hungarian Action which had to be legally appraised.

\section{Determination of the Characteristics of a Perpetrator and an Accessory Within the Nazi Regime}

\section{Basic Principles of Perpetration and Accessorial Participation}

With particular regard to the basic principles of German criminal law, Germany follows the dualistic differentiation model between principal (Täter) and accessory (Teilnehmer), governed by $\$ \$ 25-27$ StGB. ${ }^{17}$ Section 25 I StGB states that any person who commits the offense himself, or through another, shall be liable as a principal. If more than one person commits the offense jointly with another, each shall be liable as a joint principal.

An accessory is any person who intentionally induces another to intentionally commit an unlawful act - an abettor-or who assists another in the intentional commission of an unlawful act-an aider. ${ }^{18}$ The StGB remains silent, however, with regard to the criteria for demarcation between principals and accessories, and the Federal Court of Justice and criminal law commentators have propounded numerous theories on the appropriate dividing line. ${ }^{19}$

In the early stages of the German jurisdiction, the Supreme Court of the German Reich (Reichsgericht; $R G$ ) and the Federal Court of Justice adhered to an extremely subjective theory for the demarcation between principals and accessories. According to this so-called animus theory a principal is someone who objectively contributes to the main act-with the intent of being a principal (animus auctoris) thereto-and wants the act "as his own." ${ }^{20}$ Referring to the demand of the act of contribution, every kind of act, independent of its weight, could fulfill the requirement of contribution. ${ }^{21}$ Contrary to this, an accessory is someone who contributes to the main act with the intent of being an accessory (animus socii) and who wants the act as "someone else's action." 22 Thus, the decisive classification criterion was solely the intent of the accused.

Over the years, the courts have dissociated themselves from the extremely subjective theory by gaining an overall picture of the events and have taken more objective criteria of the act into consideration. According to the modified animus theory-to which the Federal Court of Justice still adheres - an indication for the classification as a perpetrator can be the accused's level of

\footnotetext{
${ }^{17}$ For further discussion about complicity, see James G. Stewart, Complicity, in The OXFord HANDBOOK OF CRIMINAL LAW 534 (Markus D. Dubber \& Tatjana Hörnle eds., 2014).

${ }^{18}$ STRAFGESETZBUCH [StGB] [Penal Code], BGBl I at $\$ 3322$, as amended by BGBl I at 3214, art. 3. I relied on the English translation by Michael Bohlander, authorized by the Federal Ministry of Justice, available at http://www.gesetze-im-intemet. de/englisch-stgb/index.html.

${ }^{19}$ Neha Jain, The Control Theory of Perpetration in International Criminal Law, 12 CHI. J. INT'L L. 159, 164 (2011).

${ }^{20}$ Reichsgericht [RG] [Supreme Court of the German Reich], Case No. 3 D 69/40, (Feb. 19, 1940), https://dejure.org/ dienste/vernetzung/rechtsprechung?Gericht=RG\&Datum $=19.02 .1940$ \&Aktenzeichen=3\%20D\%2069\%2F40 [hereinafter Judgment of Feb. 19, 1940] (followed by Bundesgerichtshof [BGH] [Federal Court of Justice] Oct. 19, 1962, ENTSCHEIDUNGEN DES BUNDESGERICHTSHOFES IN STRAFSACHEN [BGHST] 18, 87 (Ger.)).

${ }^{21} I d$.

${ }^{22} I d$.
} 
interest in the success of the offense, the type and scope of the act, the control over the act, or at least the corresponding intent to have control over the act, with the result that the commission and outcome of the crime depend on the intent of the parties involved. ${ }^{23}$ Unlike the $\mathrm{BGH}$, in recent years German law has predominantly resorted to the so-called hegemony over the act doctrine. According to this doctrine, the decisive criterion of perpetration is the hegemony and control over the execution of the criminal act. ${ }^{24}$ Accordingly, a person will be held liable as a principal if he controlled the commission of the offense, considerably influenced the shape and manner of the commission, and can be seen as the central figure of the crime. ${ }^{25}$

Contrary to this, an accessory is deemed not to be in the position of considerably shaping the commission of the offense, despite his obvious influence over the course of events. ${ }^{26}$ In this context, "the actus reus of the crime in question formally functions as a vantage point for the evaluation." 27 Both subjective and objective theories converge more and more by considering the objective contribution as well as the intention of the accused. Thus, on the basis of the aforementioned predominantly accepted mixed theory, the following forms of participation are recognized in the German system of criminal law: Physical perpetration; indirect perpetration (mittelbare Täterschaft); co-perpetration (Mittäterschaft), meaning, all considered perpetration; aiding and abetting (Beihilfe); and incitement (Anstiftung), meaning all considered as accessorial participation or Teilnahme. ${ }^{28}$

While the sole perpetrator commits the offense on his own, the word durch-through or by using, stated in $\$ 25 \mathrm{I} \mathrm{StGB}$ - signifies that the indirect perpetrator (mittelbarer Täter) controls the direct perpetrator (Tatmittler) of the criminal act in such a manner that he uses or manipulates him as a human tool or instrument. ${ }^{29}$ As to participation, $\$ \$ 26$ and 27 StGB distinguish between instigation and aiding and abetting. Both forms of participation presuppose that its object is an intentional and unlawful one. The instigator must have caused the perpetrator's intent and resolve to commit the offense, whereas the aider must have promoted or facilitated its commission. ${ }^{30}$ In the Gröning case, accessorial participation was of vital importance.

\section{Description of the Problem}

Although the differentiation between perpetrators and accessories should facilitate ranking every level of participation to its extent, its substantial significance, and its particular worthlessness of behavior, the usual theories of participation in crimes are not able to classify the available crimes adequately. ${ }^{31}$ The Holocaust implies a well-organized and established apparatus of power. The direct perpetrator can be seen as nothing but a cog in the machine, which is replaceable at any time. ${ }^{32}$ With reference to this, the chain of command compounded various levels independently of each other. Thus, each and every person contributed their action to the functioning of the Nazi homicide machinery and had a substantial effect in the perpetration of the crime. In spite of

\footnotetext{
${ }^{23}$ Bundesgerichtshof [BGH] [Federal Court of Justice] Mar. 13, 1979, ENTSCHEIDUNGEN DES BundESGERICHTSHOFES IN STRAFSACHEN [BGHST] 28, 346, 348 (Ger.); Bundesgerichtshof [BGH] [Federal Court of Justice] Sep. 15, 1988, ENTSCHEIDUNGEN DES BundesGerichtSHOFES IN STRAFSACHEN [BGHST] 35, 347, 353 (Ger.); Bundesgerichtshof [BGH] [Federal Court of Justice] July 26, 1994, ENTSCHEIDUNGEN DES BundesGerichtshofes IN STRAFSACHEN [BGHST] 40, 218, 236 (Ger.).

${ }^{24}$ George P. Fletcher, Rethinking Criminal LaW 655 (1978).

${ }^{25}$ Johannes Keiler \& David Roef, Comparative Concepts of Criminal Law 242 (2d ed. 2016).

${ }^{26}$ Claus Roxin, Strafrecht Allgemeiner Teil Band II: Besondere Erscheinungsformen der Strafta 10 (2003).

${ }^{27}$ KeIler \& RoEF, supra note 25, at 242 (emphasis added).

${ }^{28}$ Sabina Zgaga, Participation in International Criminal Law, 1 L. \& Just. Rev. 99, 124 n.103 (2011).

${ }^{29}$ Jain, supra note 19 , at 171.

${ }^{30}$ Matthias Reimann \& Joachim Zekoll, Introduction to German LaW 405 (2d ed. 2005).

${ }^{31}$ Kai Ambos, Tatherrschaft durch Willensherrschaft, in GA 226, 236 (1998).

${ }^{32}$ Igor Vuletić, "The Organised Structure of Power" and Economic Crime "FIMI-Media" Case and a View from the Croatian Perspective, 2 J.L. \& CRIM. JusT. 133, 137 (2014).
} 
this, in the present connection, the predicament is illustrated by juxtaposing the National Socialist doctor with the concentration camp guard. While the guard intimidated and menaced the deported persons, the doctor was responsible for their medical treatment and welfare. Nevertheless, with respect to the notion of assistance, both participants - through their willed conduct-indiscriminately contributed to the functioning of the machinery. Within this framework the question arises as to what extent the legislator distinguishes between the two aforementioned persons. At this point, German criminal law appears to reach its logical limits.

\section{Evolution of the Legislation}

The judgment issued by the BGH concerning Gröning's aiding and abetting during the Hungarian Action resembles former legislation on accessorial participation. After the judgment had been passed by the Supreme Court of the German Reich in the Bathtub Case in 1940, according to which the offender ought not to be convicted as a perpetrator if he commits the offense not wanting it as his own, ${ }^{33}$ the basis for the still-valid jurisprudence of the BGH regarding the subjective characteristics of the differentiation between perpetrator and accessory was established. This yields the conclusion that the Germans were-in the context of the Nazi regime-a nation of recipients of orders, but not a nation of perpetrators.

With the Amnesty Acts of 1949 and 1954, the BGH was legitimized to solely punish those carrying out mass murder as perpetrators if they were acting excessively, whereas the majority were exculpated for only being recipients of orders and consequently accessories. After the Introductory Act to the Regulatory Offences Act came into force in 1968, punishments of the accessorial participant were obligatorily reduced if specific personal characteristics that generally lead to a conviction were missing with regard to the accused. ${ }^{34}$ With its judgment in the Heinrich Case issued in 1969, the BGH stipulated that the regulations of the first and the third group of $\S$ 211 StGB are such specific personal characteristics whereupon the participants to a murder could only be convicted if they were subject to the first and third group. ${ }^{35}$ The BGH opined that the reduced sentence set the beginning of the limitation fifteen years after the end of the Second World War: $1960 .^{36}$ This judgment was the decisive cornerstone for the so-called cold amnesty, as mentioned above.

After fifty years of inactivity with regard to legislating former Nazi war crimes, the BGH prolonged the mainly subjective, theory-based stipulation regarding the accessorial participation in the case of John Demjanjuk. The judgment never acquired, however, the status of res judicata due to the death of the accused. The defining of a former SS member as an accessorial participant based on the subjective theory was finally and rightfully confirmed by the BGH in the Gröning judgment. But the BGH once again did not seize the opportunity to issue general regulations, electing instead to persist with a case-by-case analysis by applying the general regulations concerning accessorial participation to state-organized mass murders in precise consideration of the special contribution of the accused to the success of the crime. This results in a fair decision of the case on its individual merits, although at the expense of general legal certainty. Further approaches to resolve the problem of attributing acts committed during the Nazi Regime will be expounded below.

\section{Further Approaches to the Solution}

The approach taken by the BGH has frequently been condemned by the prevailing opinions of legal theorists. One such example of condemnation concerns the accountability of acts. According

\footnotetext{
${ }^{33}$ Judgment of Feb. 19, 1940 at 74, 84.

${ }^{34}$ Introductory Regulatory Offenses Act, supra note 4, at 503.

${ }^{35}$ KARL LACKNER \& KRISTIAN KÜHL, STRAFGESETZBUCH, before $\$ 211$ n.19 (28th ed. 2014).

${ }^{36}$ See 16 NJW (1181) 1181.
} 
to Fritz Bauer, the offenses committed in concentration camps could be constituted as a natural operating unit and not as legally independent acts. His theory presupposes that this was the only way to reach a non-fragmentary decision which would incorporate each offense. ${ }^{37}$ Every act itself must be treated as being engaged in the whole Nazi homicide machinery, similar in a way to an indivisible mosaic. Even the National Socialists had utilized summarized descriptions as "the final solution of the Jewish question." ${ }^{38}$ Furthermore, the National Socialists operated in a very complex and intertwined chain of command. ${ }^{39}$ As such, Bauer concluded that nobody would contrive to divide this homicide machinery into several contributions and sections. ${ }^{40}$ His theory deduces that every offense committed, from the moment a guard enters the concentration camp, partakes in the natural operating unit and has to be considered, irrespective of the individual contributions to the machinery, ${ }^{41}$ particularly as long as the intention of the guard appertains to the essential elements. ${ }^{42}$

This approach was rejected in a judgment of the $\mathrm{BGH} .{ }^{43}$ It is worth mentioning that, at this juncture, the BGH argues with the justice of an individual case ${ }^{44}$ and does not provide a well-founded legal explanation. Furthermore, this would exceed and not tally with the current legal situation regarding the accountability of acts under German criminal law. This will be examined in greater detail below.

It is questionable whether the $\mathrm{BGH}$ clearly clarified how to distinguish principals from accessories with regard to the offenses committed in concentration camps-an issue examined by Claus Roxin within his well-known theory of "indirect perpetration by means of control over an organized power structure" (mittelbare Täterschaft kraft Willensherrschaft in organisatorischen Machtapparaten). ${ }^{45}$ It derives from the doctrine of the "perpetrator behind the perpetrator" (Täter hinter dem Täter), establishing the criminal responsibility of a perpetrator due to his control over the will of the direct perpetrator, in the case of the Holocaust by means of "control over an organization" (Organisationsherrschaft). ${ }^{46}$

A principal, according to Roxin, would be a person who utilized the organized power structure to commit crimes and who was so involved in this that he would have been able to issue orders to subordinates. His theory assumes that it would be unimportant whether the principle undertook it of his own initiative or not; the decisive fact would be the circumstances under which he could direct a subordinated part of the structure. ${ }^{47}$ An accessory, however, would be a person who had no power of control and whose acts did not independently move the structure forward ${ }^{48}$ - someone who was merely a small cog in the homicide machine, fungible and exchangeable. ${ }^{49}$ Although the

\footnotetext{
${ }^{37}$ Fritz Bauer, Ideal- oder Realkonkurrenz bei nationalsozialistischen Verbrechen?, 22 JURISTENZEITUNG 625, 628 (1967).

${ }^{38}$ Bauer, supra note 37 , at 625.

${ }^{39}$ Safferling, supra note 5 , at 260.

${ }^{40}$ Bauer, supra note 37 , at 627.

${ }^{41}$ Bauer, supra note 37 , at 628 .

${ }^{42}$ Jens Rommel [LOStA, Ludwigsburg], Beteiligung am Holocaust im Konzentrationslager Auschwitz, 2017 NeUE ZEITSCHRIFT FÜr STRAFRECHT 161, 162 (referencing Bundesgerichtshof [BGH] [Federal Court of Justice] Case No. 3 StR 49/16, 498, (Sept. 20, 2016), http://juris.bundesgerichtshof.de/cgi-bin/rechtsprechung/document.py?Gericht=bgh\&Art=en\& sid=bbe46accfd2b17f4b9468d823568d02c\&nr=76630\&linked =pm\&Blank=1).

${ }^{43}$ Bundesgerichtshof [BGH] [Federal Court of Justice] Feb. 20, 1969, NeUE Juristische WochensChrift [NJW] 2056, 1969 (Ger.); Roxin, supra note 11, at 92 (agreeing).

${ }^{44}$ Safferling, supra note 5 , at 260.

${ }^{45}$ Gerhard Werle \& Boris Burghardt, Introductory Note, 9 J. INT'L CRIM. JUST. 191, 191 (2011) (discussing Claus Roxin on crimes as part of organized power structures).

${ }^{46}$ Prosecutor v. Katanga, ICC-01/04-01/07-717, Pre-Trial Chamber I, 163, 496 (Sept. 30, 2008).

${ }^{47}$ Claus Roxin, Täterschaft und TATHERRSCHAFt 248 (2015).

${ }^{48}$ Claus Roxin, Straftaten im Rahmen organisatorischer Machtapparate, 110 GOLTDAMMER's ARCHIV FÜR STRAFRECHT 193, 204 (1963).

${ }^{49}$ Wolfgang Joecks, $\$ 25$, in 1 MüNCHENER KOMMENTAR ZUM STRAFGeSETZBUCH BAND rn. 138 (Bernd von HeintschelHeinegg ed., $3 d$ ed. 2017).
} 
accessory's conduct might not vary from the behavior of the principal in terms of its reprehensibility, it should be the promotion of the homicide which must be evaluated. ${ }^{50}$

The International Criminal Court (ICC) adopted Roxin's theory in 2008 and explicitly refers to it $^{51}$ as a "legal doctrine that acknowledges the possibility that a person who acts through another may be individually criminally responsible, regardless of whether the executor (the direct perpetrator) is also responsible. This doctrine is based on the early works of Claus Roxin." 52

\section{E. Investigation of the Different Approaches}

The explanation of the different approaches mentioned above delineates the sedulous effort of legal scholars in trying to set standards for a clear dissociation between perpetration and being an accessory. It is nigh impossible, however, to set standards that facilitate a clear demarcation to fully recognize every aspect. In the following, some of the approaches will be investigated in detail to illustrate the resultant problems that occur in trying to distinguish in accordance with these theories.

The divisions of the German criminal courts invariably employed the subjective theory ${ }^{53}$ as a demarcation between perpetration and participation. ${ }^{54}$ They failed to define, however, clear standards for dissociation due to the fact that the criteria were not compelling and therefore could be weighted differently. ${ }^{55}$ As mentioned above, in accordance with this theory, someone who never had the inner attitude ${ }^{56}$ to commit the offense and only carried out the act could never be seen as a perpetrator. Therefore, only a conviction due to accessorial participation could be considered. ${ }^{57}$ Furthermore, another main crystallization point to determine whether the accused participated in or committed the crime in actuality appeared to be the presence of a command. ${ }^{58}$

In conformity with those principles, the only perpetrators that committed the vast number of heinous and inhuman crimes in the National Socialist regime would have been, strictly speaking, Hitler, Heydrich, and Himmler. Baumann characterized this outcome as "[o]ne offender and 60 million accomplices." ${ }^{\text {" Un }}$ Unurprisingly, this theory encountered, and still encounters, fierce criticism. It grants a broad margin of judgment to the trial judge on how to consider and weigh different aspects and circumstantial evidence. ${ }^{60}$ Furthermore, the BGH erred when considering the aspects concerning commands from a higher instance in the National Socialist Regime. The mere existence of a command was classified as an irrefutable piece of circumstantial evidence that indicated the offender's position as an accomplice. ${ }^{61}$

This assumption ignores the fact that the offender still potentially had influence over the crime due to the fact that the command may have been very abstract-giving the offender the scope for decision-making regarding the details of the act-thus fulfilling the criteria for

\footnotetext{
${ }^{50}$ Safferling, supra note 5, at 261.

${ }^{51}$ Claus Roxin, Zur neusten Diskussion über die Organisationsherrschaft, 159 GOLTDAMMER's ARCHIV FÜR STRAFRECHT 395, 398 (2012).

${ }^{52}$ Katanga ICC-01/04-01/07-71 at 496.

${ }^{53}$ Roxin, supra note 48, at 191, 194.

${ }^{54}$ HeinZ-Willi Heynckes, Täterschaft und TeIlnahme bei NS-Tötungsverbrechen - Analyse Und Kritik DER RECHTSPRECHUNG DES BUNDESGERICHTSHOFES 207 (2005).

${ }^{55}$ HeYNCKES, supra note 54, at 208.

${ }^{56}$ Günter Heine, Täterschaft und Teilnahme in staatlichen Machtapparaten: NS- und DDR-Unrecht im Vergleich der Rechtsprechung, 19 JURISTENZEITUNG 920, 922 (2000).

${ }^{57}$ Safferling, supra note 5, at 259; HeYNCKES, supra note 54, at 207-08.

${ }^{58}$ Falko Kruse, Das Majdanek-Urteil: Von den Grenzen deutscher Rechtsprechung, 18 KRITISCHE JusTIZ 140, 144 (1985).

${ }^{59}$ Jürgen Baumann, Beihilfe bei eigenhändiger Tatbestandserfüllung, 16 NEUE JURISTISCHE WOCHENSCHRIFT 561, 561 (1963); Jürgen Baumann, Vorsicht bei Verjährung von NS-Gewaltverbrechen! Zum Urteil des 5. Senats des BGH zur Verjährung von Beihilfe, 22 Neue JuRISTISCHE WoChENSCHRIfT 1279, 1279 (1969).

${ }^{60}$ HeYNCKES, supra note 54, at 207.

${ }^{61}$ AdAlBERT RÜCKerl, NS-VERBRECHEN VOR GERICHT 274 (1982).
} 
perpetration. ${ }^{62}$ Moreover, the recipient of orders strove to show his submissiveness towards the regime. The soldier endeavored not to create the impression of him refusing to execute the order, which indicates a personal interest in the commission of the crime, and, due to this interest, it may be argued that he had the inner attitude to commit it. ${ }^{63}$ This illustrates the significant problems that occur in applying the subjective theory.

In this context, Fritz Bauer proposed approaching the problem from a different point of view. According to him, it is not necessary to investigate every individual accusation against the accused. As mentioned above, this is due to every offense being a part of the Nazi homicide machinery. ${ }^{64}$ Therefore, it appears inappropriate to divide it into each and every single offense committed and determine whether culpability exists or not. Instead, Bauer proposed that every offense committed by a person as soon as he enters into this machinery should not be seen as individual acts, but engagement within the system as a whole. ${ }^{65}$

Initially, it appeared that this theory would provide a more satisfactory solution for dealing with crimes within the National Socialist Regime. In accordance with this theory, however, even people not closely connected with the cruel and inhuman regime, but who are still a part of it, would have had to face legal consequences due to the fact that they were still a part of National Socialism. ${ }^{66}$ "Even the doctor, who had been ordered to the care of the guard and who restricted himself to this task, would be found guilty of aiding and abetting murder. The same would even apply to the doctor who treated and saved ill concentration camp prisoners in the camp." 67 Furthermore, it appears questionable as to whether Gröning's early role in managing the prisoners' assets in the concentration camp would constitute a sufficient act as an accomplice in accordance with the accountability of acts under German criminal law. In such a role, he undoubtedly became a part of the homicide machinery, which, according to Bauer, would already place him in the role of an accomplice and thus not in any legal connection whatsoever to the process of murdering several thousand people. Therefore, it appears eminently questionable to assume a well-founded judgment that is also in conformity with the German criminal law system. ${ }^{68}$

After careful consideration, both theories do not contribute a clear standard as to how to dissociate between perpetration and participation with regards to the enormous numbers of offenses committed in concentration camps. As mentioned above, Claus Roxin also examined this issue. One important point in line with his theory was the fact that it allowed authorities to investigate both the commander and the recipient of orders and to determine whether culpability existed in the form of perpetration. By contrast, the subjective theory failed to do so. ${ }^{69}$ Despite this important accomplishment, this theory also seems to provide a well-founded legal consideration relating to the Gröning case. His role, as well as his acts in the concentration camp, did not include any power in the homicides committed, and therefore, Gröning can undoubtedly not be

\footnotetext{
${ }^{62}$ Ernst-Walter Hanack, On the Problem of Just Punishment of Nazi Violent Criminals, 2 JuristenZeitung 329, 333 (1967); Hans-Joachim Korn, Täterschaft oder Teilnahme bei staatlich organisierten Verbrechen, 18 NEUE JURISTISCHE WOCHENSCHRIFT 1206, 1206, 1209 (1965); Baumann (1963), supra note 59, at 561.

${ }^{63}$ See supra Part D.I.;HEYNCKES, supra note 54, at 212.

${ }^{64}$ Bauer, supra note 37 , at 628.

${ }^{65}$ Bauer, supra note 37, at 628; Cornelius Nestler, Warum erst jetzt? Ein Versuch zu erklären, warum es nach dem großen Frankfurter Auschwitzprozess ein halbes Jahrhundert gedauert hat, bis Oskar Gröning verurteilt wurde, in DIE LETZTEN NS-VERFAHREN 41, 63 (Frank Lüttig \& Jens Lehmann eds., 2017); Cf. Roxin, supra note 11.

${ }^{66}$ Safferling, supra note 5, at 625 .

${ }^{67} 22$ NJW 2056 (2056); Roxin, supra note 11, at 88, 92 (agreeing); Christian Fahl, Möglichkeiten und Grenzen der späten Ahndung von Teilnahmehandlungen in Auschwitz, 16 HÖCHSTRICHTERLICHE RECHTSPRECHUNG IM STRAFRECHT 210,215 (2015).

${ }^{68}$ Safferling, supra note 5 , at 260.

${ }^{69}$ HeYNCKES, supra note 54, at 224.
} 
seen as a perpetrator. Nonetheless, the accused can be clearly perceived as an accessory according to Roxin's theory, and therefore must face the legal consequences of aiding and abetting murder, which occurred due to his role as a general guard, a guard at the ramp, and an asset manager within the concentration camp.

\section{F. "Murder" and "Murder Under Specific Aggravating Circumstances"}

Both $₫ 211$ StGB, “murder under specific aggravating circumstances," and $₫ 212$ StGB, "murder," protect the legally protected right of life, which is the most highly protected legal asset under German criminal law. The criteria stipulating murder under $\$ 211$ StGB are the features used to differentiate between $₫ \$ 212$ and 211 StGB. Thereby, the criteria are present in order to accentuate the particular depravity of the perpetrator’s conduct, as $₫ 211$ StGB imposes a life sentence, the maximum penalty possible under German law. ${ }^{70}$ Concerning the criteria for murder, these have to be differentiated by dividing them into three groups, whereby all three are characterized as particularly reprehensible. Murder criteria in the first and third groups, which cover reasons and purposes of an action, pertain to the perpetrator and imply subjective characteristics of a crime. Thus, they are of major significance with regard to $\$ 28$ StGB "special personal characteristics" (besondere persönliche Merkmale). The second group, however, contains particularly reprehensible behavioral patterns which refer to the act itself, involving objective conditions. ${ }^{71}$ With reference to the offense under $₫ 212 \mathrm{StGB}$, a perpetrator will be convicted if they kill a person without fulfilling any particular murder criterion under $\$ 211$ StGB. Section 212 StGB is, arguably, not applicable with regard to former SS members. Despite the fact that most of the SS members asserted that they were merely obeying commands, a large number of them were likely acting out of racial hatred, which conceivably could be subsumed under the murder criteria contained in $\$ 211$ StGB.

In the German legal system, the "culpability principle" (Schuldprinzip) is one of the most fundamental legal principles and requires there to be proportionality between the sentence given to the accused and any wrongdoing perpetrated by him. ${ }^{72}$ Therefore, murder criteria have to be examined in order to ascertain whether $₫ 211$ StGB would be applicable to former SS members in the Gröning case. Hereinafter, clarification of three murder criteria will be presented. As mentioned above, former SS members maintained the guilelessness of their Jewish captives by disseminating untrue statements. In doing so, the perpetrators fulfilled the vital component of insidiously committing murder by stealth (Heimtücke) pursuant to $\$ 211 \mathrm{II} \mathrm{StGB}$, fifth criterion. "A person murders by stealth if he has a hostile intent. In addition, he consciously exploits the victim's guilelessness, as well as their defencelessness." 73 As such, somebody who, at the time of the action, does not anticipate an assault, is guileless. ${ }^{74}$ Consequently, somebody's defenselessness is based upon his guilelessness, so that he is incapable of defending himself or is impaired in his self-defense. ${ }^{75}$

With regard to the Holocaust, the SS members lied to the Jews in order to lead them to the gas chambers and kill them. As the Jews' defenselessness was based on their guilelessness, they were incapable of defending themselves. Thus, SS members killed by stealth.

Given the fact that in gas chambers Jews had to die through the pesticide Zyklon B, which was a hydrogen cyanide, the murder criterion of "cruelty" could also be met pursuant to $\$ 211$ II, sixth criterion.

\footnotetext{
${ }^{70} \mathrm{Cf}$. Oisín Morris, Die normative Restriktion des HeimtǘcKebegriffes Auf Basis der TeilverwirkLiCHUNG VON RECHTFERTIGUNGSGRÜNDEN 30 (2010).

${ }^{71} C f$. Rudolf Rengier, Strafrecht Besonderer Teil II 16 (17th ed. 2016).

${ }^{72} \mathrm{Cf}$. MORRIS, supra note 70 , at 28.

${ }^{73}$ LACKNER \& KÜHL, supra note 35, at 972 n.6.

${ }^{74}$ ThOMAS FISCHER, STRAFGESETZBUCH 1451 n.35 (61st ed. 2014).

${ }^{75}$ Johannes Wessels \& Michael Hettinger, Strafrecht Besonderer Teil I 40 (39th ed. 2015).
} 
Somebody kills cruelly by inflicting [upon] the victim physical or mental pain or anguish and thereby acting callously and with relentless attitude. This happens in a way that the intensity or duration necessary for killing is far exceeded. Particular physical anguish can be torture, starvation or letting somebody die of thirst. Consequently, the decisive factor is the objective infliction of substantial pain or anguish. ${ }^{76}$

As a matter of fact, Jewish victims were killed with a gas that took up to thirty minutes for death to occur. There had not been any possibility to escape from the chambers or to help their family members whose deaths they had to witness. This can undisputedly be subsumed as torturing in a particularly reprehensible way, which widely exceeds what is required for murder. Therefore, the murder criterion of "cruelty" under $\$ 211$ II StGB is indubitably applicable.

Nevertheless, a remarkably high number of Nazis acted out of racial hatred and aspired to annihilating the Jewish population, which is assuredly a political motive. "Political Motives describe an assault on fundamental values of a community." 77 Thereby, somebody who has a racist motive could act out of a base motive (niedriger Beweggrund) ${ }^{78}$ in the sense of $\$ 211$ II, fourth criterion. As during the time of National Socialism, the hatred directed towards the Jewish population was undoubtedly the main motive for slaying their community, SS members may have acted out of political motives and therefore "out of otherwise base motives" (aus sonstigen niedrigen Beweggründen) in accordance with $\$ 211$.

With reference to $\$ 28$ StGB, "special personal characteristics," - subsection 1 stipulates a possible commutation in the absence of such "special personal characteristics" which substantiate the culpability of the perpetrator. ${ }^{79}$ The characteristic is "personal" when pertaining to the perpetrator and "special" if it characterizes him. In accordance with the prevailing opinion, they both relate to the perpetrator. ${ }^{80}$ Nonetheless, some of the National Socialists only acted on the commanders' orders for fear of their own lives. Therefore, as they did not have any personal intentions or motives, they do not fulfill the requirements of any "special personal characteristics," and thus their sentences must be mitigated. ${ }^{81}$

Although the former SS members were guilty of several offenses in the legal sense, the moral aspects of their behavior should not be left unmentioned. In criminal law, establishing justice is secured by imposing a sentence in the event of a particular wrongdoing. There are numerous references concerning moral aspects, such as in the murder criterion "out of otherwise base motives." Moreover, a sentence comprises two elements: The public socio-ethical verdict and the suffering of the perpetrator. Accordingly, criminal law can be defined as a socio-ethical minimum, as retributions to some extent invariably imply a value judgment. ${ }^{82}$ In sentencing former SS members, both components are assured by conflation of the two.

\section{G. Summary}

Traditional criminal law has long ignored the question of groups as subjects of criminal actions. But in fact, our experience of the twentieth century suggests that groups have become the primary

\footnotetext{
${ }^{76}$ WOlfGang Joecks \& Christian JäGer, StudienKommentar STGB 525 n.48 (12th ed. 2018).

${ }^{77}$ Christoph Safferling, Sechzehnter Abschnitt. Straftaten gegen das Leben (\$\$ 211-222), in STRAFGESETZBUCH 1621, 1634 (Holger Matt \& Joachim Renzikowski eds., 1st ed. 2013).

${ }^{78}$ Bundesgerichtshof [BGH] [Federal Court of Justice], Case No. 5 StR 455/93, (Sept. 7, 1993), https://dejure.org/dienste/ vernetzung/rechtsprechung? Gericht=BGH\&Datum =07.09.1993\&Aktenzeichen=5\%20StR\%20455/93.

${ }^{79}$ LACKNER \& KÜHL, supra note 35, at 226 n.2.

${ }^{80}$ LACKNER \& KÜHL, supra note 35 , at 226 n.4.

${ }^{81}$ For more details about subjective elements of criminal liability, see Thomas Weigend, Mens Rea, in THE OXFORD Handbook of Criminal Law 490 (Markus Dubber \& Tatjana Hörnle eds., 2014).

${ }^{82} C f$. Verena Votteler, Das Mordmerkmal der “Sonstigen niedrigen BeWegGründe” Gem. \$211 Abs. 2 1. Gruppe 4.

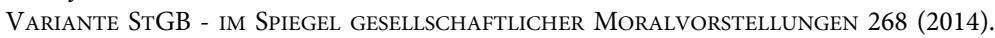


agents of criminal harm. ${ }^{83}$ Although the demarcation approaches are likely of minor significance for further National Socialist trials - as the events firmly belong to the past and, for the most part, many participants are already deceased - the decision of the BGH in the case of Oskar Gröning and the application of $\$ \$ 25-27$ StGB to organized apparatus of power still play a significant role in an era characterized by international widespread terrorism and organized crime. Membership in a criminal organization, for instance, can entail responsibility only if the accused actively took part in the acts of the organization and knew of their criminal character. ${ }^{84}$ This illustrates that the aforementioned difficulties can be transferred to various other constellations and might even be relevant for the ICC. Thus, it is desirable for the future that the law is able to draw a straight line in reference to the basic principles of perpetration and accessorial participation, and that all crimes committed can be subsumed under their specific unlawfulness.

\footnotetext{
${ }^{83}$ George Fletcher, Basic Concepts of Criminal Law 201 (1998).

${ }^{84}$ Mohamed Elewa Badar, The Concept of Mens Rea in International Criminal Law: The Case for a Unified APPROACH 246 (2013).
}

Cite this article: Bernhart F, Tanner A, Ahmad F, Galvano J, and Herde T (2020). 300,000 Counts of Aiding and Abetting Murder. German Law Journal 21, 743-755. https://doi.org/10.1017/glj.2020.40 